\title{
Physical and genetic map of the genome of Staphylococcus carnosus TM300
}

\author{
Elke Wagner, ${ }^{1}$ Jirí Doskar ${ }^{2}$ and Friedrich Götz'
}

Author for correspondence: Friedrich Götz. Tel: +497071 2974636. Fax: +497071295937.

e-mail : friedrich.goetz@uni-tuebingen.de

${ }^{1}$ Lehrstuhl für Mikrobielle Genetik, Universităt Tübingen, 72076

Tübingen, Germany

2 Department of Genetics and Molecular Biology, Faculty of Science, Masaryk University, 61137 Brno, Czech Republic

\begin{abstract}
A genome map of Staphylococcus carnosus TM300, an important microorganism in the food industry and long used as a starter culture, was constructed by pulsed-field gel electrophoresis of DNA fragments obtained after digestion with Notl, Sfil and Apal. The size of the chromosome was estimated to be $2590 \mathrm{~kb}$. The fragments were assembled into a physical map using a combination of complementary methods including multiple and partial digests of genomic DNA, hybridization with homologous gene probes, and cross-Southern hybridization. Fifteen genes or gene clusters were positioned on the physical map by Southern hybridization analysis. The map provides a basis for further analysis of the $S$. carnosus chromosome.
\end{abstract}

Keywords: Staphylococcus carnosus, genome mapping

\section{INTRODUCTION}

It has been known for a long time that Gram-positive and catalase-positive cocci play an important role in the ripening process of dry sausages. The predominant micro-organism in fermented meat is Staphylococcus carnosus, referred to in the early literature as Micrococcus (Götz \& Schleifer, 1983; Lerche \& Sinell, 1955; Niinivaara \& Pohja, 1956). On the basis of modern taxonomic criteria such as DNA sequence homology, chemical composition of the peptidoglycan, and biochemical properties, the organism was reclassified as a new staphylococcal species, S. carnosus; the species name of the bacterium is derived from its occurrence in meat (Schleifer \& Fischer, 1982). Since the 1950s, S. carnosus has been used alone or in combination with other micro-organisms, such as pediococci or lactobacilli, as a starter culture for the production of raw sausage. The main positive characteristics of $S$. carnosus in this process are its ability to reduce nitrate, to develop a characteristic flavour, to lower the $\mathrm{pH}$ moderately, and to reduce hydrogen peroxide produced by the catalase-negative lactobacilli (Liepe, 1982).

$S$. carnosus has only a low DNA sequence homology with $S$. aureus and other staphylococcal species. It produces no toxins, haemolysins, protein A, coagulase, or clumping factors, markers which are typical for many $S$. aureus strains. As $S$. carnosus is such a commercially useful micro-organism, we thought it particularly worthwhile to develop a gene cloning system for it (Götz, 1986, 1990a, b). Among the various S. carnosus strains we chose $S$. carnosus strain TM 300 because of its low extracellular proteolytic activity. Transformation systems have been worked out for this strain (Augustin \& Götz, 1990; Götz et al., 1983; Götz \& Schumacher, 1987) and suitable cloning vectors have been developed (Kreutz \& Götz, 1984; Rosenstein et al., 1992; Wieland et al., 1995). S. carnosus TM300 is used as an alternative host organism not only in molecular genetics to study staphylococcal-related pathways (Augustin et al., 1992; Ayora \& Götz, 1994; Heilmann et al., 1996; Neubauer \& Götz, 1996; Wieland et al., 1994) but also to produce and secrete heterologous proteins or to display the proteins on the cell surface (Demleitner \& Götz, 1994; Liebl \& Götz, 1986; Samuelson et al., 1995; Strauss \& Götz, 1996; Thumm \& Götz, 1997).

Despite the establishment of a host vector system and the availability of many cloned genes, the structure and organization of the $S$. carnosus genome is not well defined.

Recently the genomes of 47 coagulase-negative staphylococcal strains (CNSs) assigned to different species were analysed by pulsed-field gel electrophoresis (PFGE) (Snopková et al., 1994). The strains were clustered on the basis of their similarity in the SmaI restriction patterns into various groups, which fitted well with the classification scheme of CNSs. It was also demonstrated that by comparison of genome restriction patterns, so far uncharacterized CNSs could be allocated to certain species.

PFGE (Schwartz \& Cantor, 1984) has proved to be an 
efficient method for genome size estimation and construction of chromosomal maps as well as being a useful tool for the epidemiological analysis of bacterial species. The construction of physical maps has provided much information on the number and topology of chromosomes, the location of genes, and the genomic flexibility and structural conservation of a given species by comparative mapping of stains. Genome mapping might be considered out of fashion in the days of genome sequencing projects. However, a thoroughly worked out genomic map, such as that of $S$. aureus (Pattee et al., 1990), is an extremely valuable basis for starting genome sequencing.

Here we present a physical map of the chromosome of $S$. carnosus. The map was constructed by PFGE of fragments generated by restriction enzymes that cut rarely, in combination with the hybridization of specific gene probes. The generation of a physical map for this organism will help direct future identification, gene cloning, fine mapping strategies and genome sequencing.

\section{METHODS}

Preparation of DNA for PFGE. DNA was prepared in agarose blocks by previously described methods (Linhardt et al., 1992; Prévost et al., 1992) with some modifications. S. carnosus TM300 was grown in $20 \mathrm{ml} 2 \times \mathrm{YT}$ medium at $37^{\circ} \mathrm{C}$ to an $\mathrm{OD}_{578}$ of 0.2 . After addition of $200 \mu \mathrm{l} 0.5 \mathrm{M}$ EDTA (pH 8.0) the bacteria were harvested, washed twice in $2 \mathrm{ml}$ of a buffer containing $10 \mathrm{mM}$ Tris/ $\mathrm{HCl}(\mathrm{pH} 7 \cdot 5), 10 \mathrm{mM}$ EDTA, $10 \mathrm{mM}$ EGTA and $1 \mathrm{M} \mathrm{NaCl}$, resuspended in $200 \mu \mathrm{l}$ of the same buffer, and stored at $55^{\circ} \mathrm{C}$. A 7-10 $\mu$ l volume of a lysostaphin (Sigma) stock solution $\left(0.5 \mathrm{mg} \mathrm{ml}^{-1}\right)$ was added to $100 \mu$ lof the suspension, which was then immediately mixed with $100 \mu \mathrm{l}$ $2 \%$ low-melting-point agarose (BRL) in $50 \mathrm{mM}$ Tris/ $\mathrm{HCl}$ (pH 8.0), 5 mM EDTA. The mixture was cast in moulds to form agarose blocks, which were subsequently transferred into $1 \mathrm{ml}$ lysis buffer [6 mM Tris/ $\mathrm{HCl}$ (pH 7.6), $100 \mathrm{mM}$ EDTA, $1 \mathrm{M} \mathrm{NaCl}, 0.5 \%$ Brij $58,0 \cdot 2 \%$ sodium deoxycholate, $0.5 \% \mathrm{~N}$-lauroylsarcosine, $\mathrm{pH} 7 \cdot 6$ ] supplemented with $500 \mu \mathrm{g}$ lysozyme (Boehringer Mannheim)] and incubated for 2-3 h at $37^{\circ} \mathrm{C}$. The lysis buffer was then replaced with $1 \mathrm{ml}$ proteolysis buffer [0.25 M EDTA, $20 \mathrm{mM}$ EGTA, $1 \%$ (v/v) N-lauroylsarcosine] containing $500 \mu \mathrm{g}$ proteinase $\mathrm{K}$ (Boehringer Mannheim). Digestion was performed for $12 \mathrm{~h}$ at $55^{\circ} \mathrm{C}$. The agarose blocks were washed five times with $10 \mathrm{ml} \mathrm{TE}$ buffer and stored at $4{ }^{\circ} \mathrm{C}$ in TE buffer.

Endonuclease digestion and PFGE. Digestions of the highmolecular-mass DNA were performed with different restriction endonucleases purchased from Boehringer Mannheim (NotI, SfiI, ApaI, EclXI, KspI, BssHII), New England Biolabs (AscI), Amersham (Sse8387I), BRL (SmaI) and Promega (SgfI). The agarose blocks were cut into pieces $(2 \times 1 \times 4 \mathrm{~mm})$, which were incubated with $10-20 \mathrm{U}$ of the enzyme in a final volume of $100 \mu \mathrm{l}$ for $2-4 \mathrm{~h}$ at the required reaction temperature. Multiple digestions were done sequentially by washing the agarose pieces and changing the buffer to the appropriate one between the incubations. Some double digestions were analysed by two-dimensional PFGE. After digestion with one enzyme and electrophoresis in one dimension, DNA fragments contained in excised gel blocks were digested with 50-200 U of the second enzyme. The gel blocks were embedded in a second, slightly thicker gel, and electrophoresis was carried out. For partial digestion, the DNA agarose pieces were incubated overnight at $4^{\circ} \mathrm{C}$ in reaction buffer without magnesium and $10 \mathrm{U}$ of enzyme. After the addition of $10-40 \mu \mathrm{l}$ $1 \mathrm{mM}$ magnesium chloride, the mixture was incubated for $1 \mathrm{~h}$ at the appropriate reaction temperature. The reaction was stopped by adding $5 \mu 10.5 \mathrm{M}$ EDTA. PFGE was performed in a contour-clamped homogeneous-electric-field apparatus (CHEF-DR II) from Bio-Rad. Agarose gels were prepared at $1-1.2 \%$ in $1 \times$ TAE buffer. Fragments were separated at $14{ }^{\circ} \mathrm{C}$ and at a constant voltage of $170 \mathrm{~V}$ with pulse times varying with the size range. To check for the existence of fragments smaller than $15 \mathrm{~kb}$, all digests were systematically resolved by conventional gel electrophoresis. Saccharomyces cerevisiae chromosomes, bacteriophage lambda DNA concatemers from cI857S7, MidRange PFG Marker I [bacteriophage lambda DNA concatemers from cI857S7 and Xhol-digested lambda DNA (New England Biolabs)], and MidRange PFG Marker II [bacteriophage lambda DNA concatemers and XbaI-digested lambda DNA (New England Biolabs)] were used as molecular size standards. Gels were stained for $1 \mathrm{~h}$ in ethidium bromide $\left(0.5 \mathrm{mg} \mathrm{ml}^{-1}\right)$, destained in water, and photographed under ultraviolet light.

DNA hybridization and genomic DNA probes. Restriction fragments were transferred onto positively charged nylon membranes (Boehringer Mannheim) by a modified Southern transfer procedure (Dubitsky et al., 1992). After electrophoresis, DNA fragments were depurinated in $0.25 \mathrm{M} \mathrm{HCl}$ for $10 \mathrm{~min}$ and were then denatured in $0.5 \mathrm{M} \mathrm{NaOH} / 1.5 \mathrm{M} \mathrm{NaCl}$ for $30 \mathrm{~min}$. A dry membrane was placed on the alkaline gel. For transfer, $20 \times \mathrm{SSC}(3 \mathrm{M} \mathrm{NaCl} / 0.3 \mathrm{M}$ sodium citrate, $\mathrm{pH} 7 \cdot 0$ ) was used. The DNA was bound to the membrane by baking at $120^{\circ} \mathrm{C}$ for $30 \mathrm{~min}$. Probes were prepared by randomprimed DNA labelling with DIG-High Prime (Boehringer Mannheim). CSPD (disodium 3-(4-methoxyspiro\{1,2-dioxetane-3,2'-(5'-chloro) tricyclo[3.3.1.1 $\left.1^{3,7}\right]$ decan $\left.\}-4-y l\right)$ phenyl phosphate from Boehringer Ingelheim Bioproducts) was used for chemiluminescent detection of the DNA. Stripping and reprobing were performed as recommended by the membrane manufacturer.

\section{RESULTS}

\section{Selection of restriction endonucleases and determination of the genome size}

Restriction endonucleases were tested for their ability to digest the $S$. carnosus chromosome into a small number of fragments that could be resolved well by PFGE. Due to the low $\mathrm{G}+\mathrm{C}$ content $(35-36 \mathrm{~mol} \%$ ) of $S$. carnosus (Schleifer \& Fischer, 1982), enzymes were tested that recognize G+C-rich sequences. The enzymes ApaI, NotI, Sfil, Sse8387I and SmaI each cleaved the genome into a convenient number of fragments with suitable sizes for PFGE. NotI, SfiI and ApaI produced 3, 3 and 12 restriction fragments, respectively (Table 1, Fig. 1) and were chosen for mapping the genome of $S$. carnosus. The sizes of the largest Not I fragment (No1), the largest Sfil fragment (Sf1) and the NoSf1 fragment were determined under different parameters as used for the PFGE gel in Fig. 1 (data not shown). The two smallest fragments of the ApaI digest were not observed in PFGE gels, but could be detected by conventional electrophoresis (data not shown). Sse8387I and SmaI cut the DNA into 13 and 23 fragments, respectively. Further 


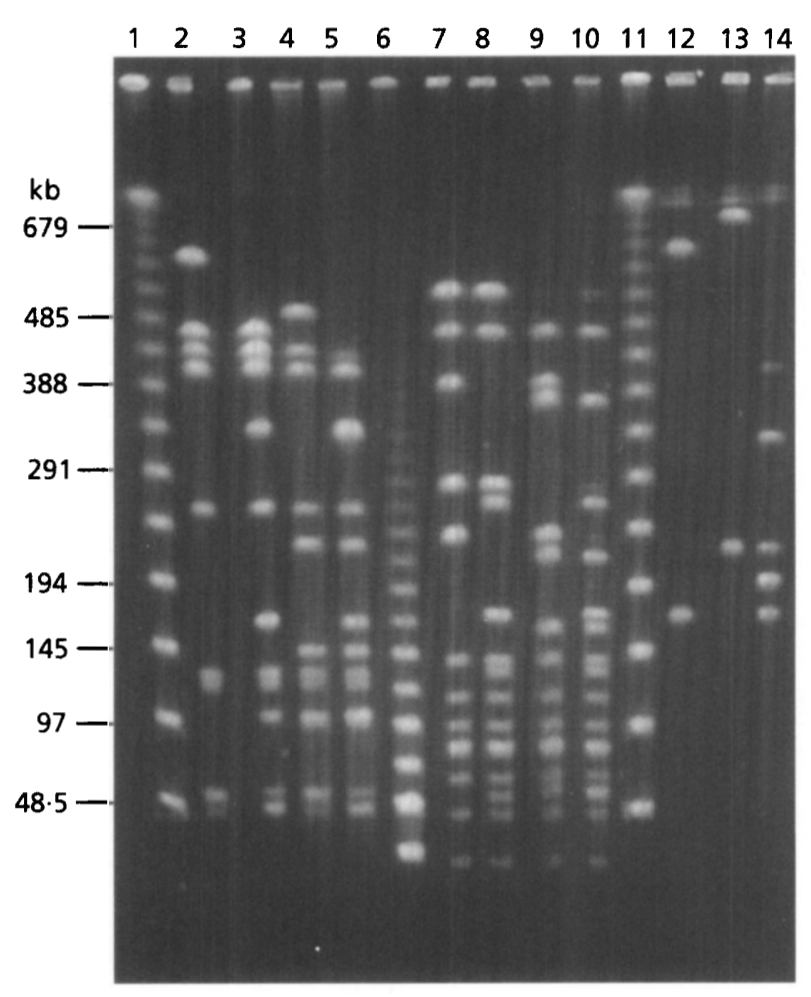

Fig. 1. PFGE separation of DNA from S. carnosus digested with Apal, Notl, Sfil and Sse8387I. Migration parameters: $1 \%$ agarose, pulse times from 5 to $65 \mathrm{~s}$ at $170 \mathrm{~V}$ for $36 \mathrm{~h}$. Lanes: 1 , lambda DNA concatemers; 2, Apal digestion; 3, Apal-Notl digestion; 4, Apal-Sfil digestion; 5, Apal-Notl-Sfil digestion; 6, MidRange PFG Marker II; 7, Sse8387I digestion; 8, Sse8387I-NotI digestion; 9, Sse8387I-Sfil digestion; 10, Sse83871-Notl-Sfil digestion; 11, lambda DNA concatemers; 12, Notl digestion; 13, Sfil digestion; 14, Notl-Sfil digestion.

analysis by Sse $8387 \mathrm{I}$ digests was required to arrange some ApaI fragments and to confirm the results obtained with ApaI, NotI and SfiI. Among the other restriction enzymes tested, AscI, FseI and SgfI did not cut the genome. BssHII, EclXI and KspI cut the DNA too frequently to be of use for macrophysical mapping.

The size of the $S$. carnosus genome was estimated to be $2590 \mathrm{~kb}$ by adding together the sizes of the fragments from each of the NotI, SfiI, ApaI and Sse8387I digests (Table 1).

\section{Alignment of Notl and Sf fragments in the $S$. carnosus genome}

NotI-Sfil double digests were performed to locate the restriction sites for NotI in relation to those for $S f i \mathrm{I}$ on the chromosome. After single digestions, NotI and SfiI each generated three fragments. After double digestion, six fragments were detected (Table 1). These numbers of fragments were consistent with a circular map of the chromosome. Only five electrophoretically distinct bands were produced. The band at about $200 \mathrm{~kb}$ contained two comigrating DNA fragments (Fig. 1). The two largest NotI and the two largest SfI fragments disappeared after double digestion, indicating that they contained SfiI and NotI sites, respectively. By comparing the fragment sizes obtained, one NotI site was localized on the Sf1 fragment, one SfiI site on the No1 fragment, two NotI sites on the Sf 2 fragment, and two SfiI sites on the No2 fragment. To confirm these results, consecutive double digestions with NotI and Sfil were analysed by two-dimensional PFGE. The restriction fragments generated, summarized in Table 2, were in accordance with the results obtained by comparing the fragment sizes of the single and double digestions with NotI and Sfil. Hybridization experiments with various gene probes against DNA digested with NotI, Sfil and NotI-Sfil were also performed to identify the overlapping fragments. The hybridization results are given in Table 3. By using the hybridization data and by combinatorial analyses of the fragments obtained after single, double, and consecutive double digestions, we were able to map all of the NotI and SfiI sites.

\section{Alignment of Apal fragments in the S. carnosus genome}

Apal cleaved the $S$. carnosus chromosome into 12 restriction fragments (Table 1). The Ap11 and Ap12 fragments could only be detected by conventional electrophoresis and the Ap8 and Ap 9 fragments formed a doublet. Therefore, only nine distinct bands could be identified (Fig. 1). Double digestions with ApaI and NotI or $S f \mathrm{II}$ and triple digestions with these enzymes were performed to locate the ApaI sites in relation to the other restriction sites. In both ApaI-NotI and ApaI-Sfi double digestions, 15 fragments were generated; 18 fragments were generated in ApaI-NotI-SfiI triple digestions (Table 1). The Ap1, Ap3 and Ap8 fragments disappeared in the NotI-ApaI double digestion (Fig. 1), indicating that each carried one NotI site. Similarly the Ap1 fragment was found to contain one SfiI site, and the Ap2 fragment two Sfil sites. Consecutive double digestions of some isolated ApaI fragments with NotI and Sfi (Table 2) and hybridization experiments with various gene probes (Table 3 ) were also performed. It was possible to map the Ap1, Ap2 and Ap3 fragments in relation to the NotI and $S$ fiI restriction sites by combinatorial analysis of the fragments. The Ap2 and Ap3 fragments are located next to each other, and the Ap1 fragment is separated by approximately $60 \mathrm{~kb}$ from the Ap2 fragment. The $52 \mathrm{~kb}$ Ap8 fragment is localized in this gap because it disappeared in the NotI-ApaI digest (Fig. 1) and two additional fragments with sizes of about $43 \mathrm{~kb}$ and $6.5 \mathrm{~kb}$ were found.

To determine which of the two smallest ApaI fragments, the $7.8 \mathrm{~kb} \mathrm{Ap} 11$ or the $5.2 \mathrm{~kb}$ Ap12 fragment, is positioned in the remaining gap of about $8 \mathrm{~kb}$, crossSouthern hybridization was performed. The Ap11 and Ap12 fragments were used to probe blots of genomic digests created by NotI, SfiI and Sse8387I. The Ap12 probe hybridized to a $200 \mathrm{~kb} N o t I-S f i$ fragment (data 
Table 1. Restriction fragments of $S$. carnosus

The total sizes of NotI, Sfil, NotI-Sfil, ApaI, ApaI-NotI, ApaI-Sfil, ApaI-NotI-Sfil and Sse8387I were 2560 $\pm 112,2588 \pm 105$, $2583 \pm 115,2606 \pm 78,2591 \pm 79,2614 \pm 79,2603 \pm 83$ and $2575 \pm 85 \mathrm{~kb}$, respectively.

\begin{tabular}{|c|c|c|c|c|c|c|c|c|c|c|c|c|c|c|c|}
\hline \multicolumn{16}{|c|}{ Name* and size $(\mathrm{kb})+$ of fragments: } \\
\hline \multicolumn{2}{|c|}{ NotI } & \multicolumn{2}{|c|}{ SfiI } & \multicolumn{2}{|c|}{ NotI-SfiI } & \multicolumn{2}{|c|}{ Apal } & \multicolumn{2}{|c|}{ ApaI-NotI } & \multicolumn{2}{|c|}{ Apal-SfiI } & \multicolumn{2}{|c|}{ ApaI-NotI-SfiI } & \multicolumn{2}{|c|}{ Sse8387I } \\
\hline Fragment & Size & Fragment & Size & Fragment & Size & Fragment & Size & Fragment & Size & Fragment & Size & Fragment & Size & Fragment & Size \\
\hline No1 & $1750 \pm 90$ & Sf1 & $1650 \pm 80$ & NoSf1 & $1450 \pm 80$ & Ap1 & $600 \pm 16$ & ApNo1 & $470 \pm 12$ & ApSf1 & $510 \pm 13$ & ApNoSf1 & $415 \pm 12$ & Ss1 & $540 \pm 12$ \\
\hline No2 & $635 \pm 16$ & Sf2 & $710 \pm 18$ & NoSf2 & $330 \pm 10$ & Ap2 & $470 \pm 12$ & ApNo2 & $435 \pm 12$ & ApSf2 & $\begin{array}{c}445 \pm 12 \\
(\mathrm{Ap} 3)\end{array}$ & ApNoSf2 & $345 \pm 10$ & Ss2 & $470 \pm 12$ \\
\hline \multirow[t]{15}{*}{ No3 } & $175 \pm 6$ & Sf3 & $228 \pm 7$ & NoSf3 & $\begin{array}{c}228 \pm 7 \\
(\mathrm{~S} f 3)\end{array}$ & Ap3 & $445 \pm 12$ & ApNo3 & $\begin{array}{c}415 \pm 12 \\
(\mathrm{Ap} 4)\end{array}$ & ApSf3 & $\begin{array}{c}415 \pm 12 \\
(\mathrm{Ap} 4)\end{array}$ & ApNoSf3 & $335 \pm 10$ & Ss 3 & $395 \pm 10$ \\
\hline & & & & NoSf 4 & $200 \pm 6$ & Ap4 & $415 \pm 12$ & ApNo4 & $330 \pm 10$ & ApSf4 & $\begin{array}{c}260 \pm 8 \\
\text { (Ap5) }\end{array}$ & ApNoSf4 & $260 \pm 8$ & Ss 4 & $287 \pm 8$ \\
\hline & & & & NoSf5 & $200 \pm 6$ & Ap5 & $260 \pm 8$ & ApNo5 & $\begin{array}{c}257 \pm 8 \\
(\text { Ap } 5 \text { ) }\end{array}$ & ApSf5 & $\begin{array}{c}226 \pm 7 \\
(\mathrm{Sf} 3)\end{array}$ & ApNoSf5 & $226 \pm 7$ & Ss5 & $238 \pm 8$ \\
\hline & & & & NoSf6 & $\begin{array}{c}175 \pm 6 \\
(\mathrm{No} 3)\end{array}$ & Ap6 & $132 \pm 5$ & ApNo6 & $165 \pm 6$ & ApSf6 & $145 \pm 5$ & ApNoSf6 & $165 \pm 6$ & Ss6 & $142 \pm 6$ \\
\hline & & & & & & Ap7 & $124 \pm 5$ & ApNo7 & $\begin{array}{c}132 \pm 5 \\
\text { (Ap6) }\end{array}$ & ApSf7 & $\begin{array}{c}132 \pm 5 \\
\text { (Ap6) }\end{array}$ & ApNoSf7 & $145 \pm 5$ & Ss7 & $115 \pm 6$ \\
\hline & & & & & & Ap8 & $52 \pm 2$ & ApNo8 & $\begin{array}{c}124 \pm 5 \\
(\mathrm{Ap} 7)\end{array}$ & ApSf8 & $\begin{array}{c}124 \pm 5 \\
(\mathrm{Ap} 7)\end{array}$ & ApNoSf8 & $130 \pm 5$ & Ss8 & $97 \pm 5$ \\
\hline & & & & & & Ap 9 & $52 \pm 2$ & ApNo9 & $100 \pm 3$ & ApSf 9 & $100 \pm 3$ & ApNoSf 9 & $125 \pm 5$ & Ss9 & $83 \pm 5$ \\
\hline & & & & & & Ap10 & $43 \pm 2$ & ApNo10 & $\begin{array}{l}52 \pm 2 \\
(\text { Ap9) }\end{array}$ & ApSf10 & $97 \pm 3$ & ApNoSf10 & $100 \pm 3$ & Ss 10 & $83 \pm 5$ \\
\hline & & & & & & Ap11 & 7.8 & ApNo11 & $\begin{array}{c}43 \pm 2 \\
(\mathrm{Ap} 10)\end{array}$ & ApSf11 & $\begin{array}{l}52 \pm 2 \\
(\text { Ap } 8)\end{array}$ & ApNoSf11 & $100 \pm 3$ & Ss11 & $62 \pm 4$ \\
\hline & & & & & & Ap12 & $5 \cdot 2$ & ApNo12 & $43 \pm 2$ & ApSf12 & $\begin{array}{l}52 \pm 2 \\
\text { (Ap9) }\end{array}$ & ApNoSf12 & $97 \pm 3$ & Ss12 & $43 \pm 3$ \\
\hline & & & & & & & & ApNo13 & $7 \cdot 8($ Ap11) & ApSf13 & $\begin{array}{c}43 \pm 2 \\
(A p 10)\end{array}$ & ApNoSf13 & $52 \pm 2$ & Ss 13 & $20 \pm 1$ \\
\hline & & & & & & & & ApNo14 & 6.5 & ApSf14 & $\begin{array}{c}7.8 \\
\text { (Ap11) }\end{array}$ & ApNoSf14 & $43 \pm 2$ & & \\
\hline & & & & & & & & ApNo15 & $5 \cdot 2$ (Ap12) & ApSf15 & $5 \cdot 2($ Ap12) & ApNoSf15 & $43 \pm 2$ & & \\
\hline & & & & & & & & & & & & $\begin{array}{l}\text { ApNoSt16 } \\
\text { ApNoSf17 }\end{array}$ & 6.5 & & \\
\hline & & & & & & & & & & & & ApNoSf18 & $5 \cdot 2$ & & \\
\hline
\end{tabular}

*Each restriction fragment was named by the initial letters of the enzyme used to produce it (No, NotI; Sf, SfiI; Ap, ApaI; Ss, Sse8387I). Fragments obtained from multiple digestions were also named with the initial letters of the enzymes used (NoSf, NotI-SfiI; ApNo, ApaI-NotI; ApSf, ApaI-SfiI; ApNoSf, ApaI-NotI-Sfil). The fragments from each digest were numbered in order, from the largest to the smallest.

† The size indicated is the mean of at least four independent values \pm the standard deviation from the mean.

Table 2. Products of consecutive double digestions

\begin{tabular}{|c|c|c|}
\hline First/second enzyme & Restriction fragment & $\begin{array}{l}\text { Fragments obtained after the } \\
\text { second digestion }\end{array}$ \\
\hline \multirow[t]{2}{*}{$\operatorname{Not} \mathrm{I} / S f \mathrm{I}$} & No2 $(635 \pm 16 \mathrm{~kb})$ & $\begin{array}{l}225 \mathrm{~kb}(\mathrm{Sf} 3), 200 \mathrm{~kb}(\mathrm{NoSf} 4) \\
200 \mathrm{~kb}(\mathrm{NoSf} 5)\end{array}$ \\
\hline & No3 $(175 \pm 6 \mathrm{~kb})$ & $175 \mathrm{~kb}(\mathrm{No} 3)$ \\
\hline \multirow[t]{3}{*}{ Sfil/NotI } & Sf1 $(1650 \pm 80 \mathrm{~kb})$ & $1500 \mathrm{~kb}$ (NoSf1), $200 \mathrm{~kb}$ (NoSf4) \\
\hline & Sf $2(710 \pm 18 \mathrm{~kb})$ & $\begin{array}{l}330 \mathrm{~kb} \text { (NoSf2), } 200 \mathrm{~kb} \text { (NoSf5), } \\
170 \mathrm{~kb}(\mathrm{No} 3)\end{array}$ \\
\hline & $\mathrm{Sf} 3(228 \pm 7 \mathrm{~kb})$ & $230 \mathrm{~kb}(\mathrm{Sf} 3)$ \\
\hline \multirow[t]{2}{*}{ ApaI/NotI } & Ap1 $(600 \pm 16 \mathrm{~kb})$ & $430 \mathrm{~kb}(\mathrm{ApNo} 2), 160 \mathrm{~kb}(\mathrm{ApNo})$ \\
\hline & Ap3 $(445 \pm 12 \mathrm{~kb})$ & $330 \mathrm{~kb}(\mathrm{ApNo} 4), 100 \mathrm{~kb}(\mathrm{ApNo} 9)$ \\
\hline \multirow[t]{2}{*}{$A p a \mathbf{I} / S f i \mathrm{I}$} & Ap1 $(600 \pm 16 \mathrm{~kb})$ & $510 \mathrm{~kb}(\mathrm{ApSf} 1), 97 \mathrm{~kb}(\mathrm{ApSf} 9)$ \\
\hline & Ap2 $(470 \pm 12 \mathrm{~kb})$ & $\begin{array}{l}220 \mathrm{~kb}(\mathrm{Sf} 3), 145 \mathrm{~kb}(\mathrm{ApSf} 5) \\
100 \mathrm{~kb}(\mathrm{ApSf} 8)\end{array}$ \\
\hline \multirow[t]{3}{*}{ Sse8387I/ApaI } & Ss1 $(540 \pm 12 \mathrm{~kb})$ & $270 \mathrm{~kb}, 260 \mathrm{~kb}$ \\
\hline & Ss $2(470 \pm 12 \mathrm{~kb})$ & $260 \mathrm{~kb}, 120 \mathrm{~kb}, 70 \mathrm{~kb}$ \\
\hline & Ss3 $(395 \pm 10 \mathrm{~kb})$ & $360 \mathrm{~kb}, 30 \mathrm{~kb}$ \\
\hline
\end{tabular}


Table 3. Assignment of genetic markers to the physical map of S. carnosus

\begin{tabular}{|c|c|c|c|}
\hline Probe & Gene function & $\begin{array}{l}\text { Hybridizing } \\
\text { fragments }\end{array}$ & Reference* \\
\hline ald genes & Aldehyde dehydrogenases & $\begin{array}{r}\text { No1, Sf1, NoSf1, Ap1, ApNo3, } \\
\text { ApSf10, ApNoSf11, Ss1, SsSf3 }\end{array}$ & K. Nikoleit, unpublished \\
\hline$f d a$ & $\begin{array}{l}\text { Fructose-1,6-bisphosphate } \\
\text { aldolase }\end{array}$ & $\begin{array}{r}\text { No1, Sf1, NoSf1, Ap1, ApNo3, } \\
\text { ApSf10, ApNoSf11, Ss1, SsSf3 }\end{array}$ & Witke \& Götz (1993) \\
\hline$g l c A, g l c B$ & $\mathrm{EII}^{\mathrm{Glc}} 1, \mathrm{EII}{ }^{\mathrm{Glc}} 2$ & $\begin{array}{l}\text { No1, Sf1, NoSf1, Ap3, ApNo4, } \\
\text { ApNoSf3, Ss3 }\end{array}$ & $\begin{array}{l}\text { Christiansen \& Hengstenberg } \\
\text { (1996) }\end{array}$ \\
\hline$l s p$ & Signal peptidase II & $\begin{array}{l}\text { No1, Sf1, NoSf1, Ap3, ApNo4, } \\
\text { ApNoSf3, Ss2 }\end{array}$ & Witke \& Götz (1995) \\
\hline moe & $\begin{array}{l}\text { Molybdenum cofactor } \\
\text { biosynthesis gene cluster }\end{array}$ & No1, Sf1, NoSf1, Ap4, Ss1, SsSf3 & $\begin{array}{l}\text { H. Neubauer and others, } \\
\text { unpublished }\end{array}$ \\
\hline$m t l D, m t l F, m t l A$ & $\begin{array}{l}\text { Mannitol-1-phosphate } \\
\text { dehydrogenase, EIII }{ }^{\mathrm{Mtl}}, \mathrm{EII}^{\mathrm{Mtl}}\end{array}$ & No1, Sf1, NoSf1, Ap10, Ss6 & Fischer \& Hengstenberg (1992) \\
\hline nir/nar & $\begin{array}{l}\text { Nitrite reduction gene } \\
\text { cluster/nitrate reductase }\end{array}$ & No1, Sf1, NoSf1, Ap4, Ss1, SsSf3 & I. Pantel and others, unpublished \\
\hline$p t s H, p t s I$ & $\mathrm{HPr}$, enzyme I & $\begin{array}{l}\text { No2, Sf1, NoSf4, Ap3, ApNo9, } \\
\text { Ss3 }\end{array}$ & Kohlbrecher et al. (1992) \\
\hline$r p l M, r p s I$ & Ribosomal proteins L13, S9 & No1, Sf1, NoSf1, Ap4, Ss8 & $\begin{array}{l}\text { Overhoff-Freundlieb \& Freudel } \\
\text { (1991) }\end{array}$ \\
\hline rRNA genes & $16 \mathrm{~S}$ rRNA, 23S rRNA & No3, Ap4, Ap6, Ap8, Ss5, Ss6 & P. Nerf \& F. Götz, unpublished \\
\hline sceA & Exoprotein & No1, Sf1, NoSf1, Ap9, Ss6 & $\begin{array}{l}\text { B. Krismer and others, } \\
\text { unpublished }\end{array}$ \\
\hline$s c e B$ & Exoprotein & No1, Sf1, NoSf1, Ap4, Ss8 & $\begin{array}{l}\text { B. Krismer and others, } \\
\text { unpublished }\end{array}$ \\
\hline $\sec A$ & Protein export & No2, Sf3, Ap2, Ss4 & Klein et al. (1995) \\
\hline $\sec E, n u s G, r p l K$ & $\begin{array}{l}\text { Protein export, termination } \\
\text { protein, ribosomal protein L11 }\end{array}$ & $\begin{array}{l}\text { No2, Sf2, NoSf5, Ap2, ApSf6, } \\
\text { Ss13 }\end{array}$ & Meens et al. (1994) \\
\hline $\sec Y$ & Protein export & No1, Sf1, NoSf1, Ap4, Ss8 & Tschauder et al. (1992) \\
\hline
\end{tabular}

*All the unpublished work cited here was done at the Lehrstuhl für Mikrobielle Genetik, Universität Tübingen.

not shown) and to the $238 \mathrm{~kb}$ Ss5 fragment (Fig. 2). No hybridization signal was obtained with NotI- or Sfildigested DNA. Because of the occurrence of two $200 \mathrm{~kb}$ NotI-Sfil fragments we could not localize Ap12. Therefore the arrangement of some Sse8387I fragments was determined by analysing double digestions with NotI and Sfil. Sse8387I cleaved the $S$. carnosus chromosome into 13 restriction fragments (Table 1 ). Only 12 distinct bands appeared on the gel because the Ss9 and Ss10 fragments formed a doublet (Fig. 1). We could show that the Ss 5 fragment carried two NotI sites and is therefore localized in the region of No3. The Ss3 fragment contained one NotI site and therefore overlaps with the No1 and No2 fragments. The Ss1 fragment carried one Sfil site and represented the overlapping fragment of Sf1 and Sf2. Two Sfil sites were found on the Ss4 fragment. Information on the hybridization of probes was important in verifying the arrangement of these fragments. Consecutive double digestions of specific Sse8387I fragments with $A p a \mathrm{I}$ were also performed. The sizes of the resulting fragments are given in Table 2. The digestion of the Ss 1 fragment with ApaI yielded two fragments, of about 270 and $260 \mathrm{~kb}$. The $270 \mathrm{~kb}$ ApaI-Sse8387I fragment and the Ss1 fragment showed (part of) the same hybridization pattern as the Ap4 fragment. This indicated that the Ss 1 fragment is positioned in the region of the Ap4 fragment and next to the Ap1 fragment, which also showed (part of) the same hybridization pattern as Ss1. The Ss2 fragment was aligned next to the $\mathrm{Ss} 3$ fragment, which is located in the region of Ap3, because the lsp gene probe hybridized to both the Ss2 and the Ap3 fragment, showing that these were overlapping fragments.

The arrangement of ApaI fragments in the region of the Ss 2 fragment was also determined by consecutive double digestions with ApaI. Fragments were obtained with sizes of about 260, 120 and $70 \mathrm{~kb}$ (Table 2). The $70 \mathrm{~kb}$ fragment represented the overlapping ApaI-Sse8387I fragment, which hybridized to the $l s p$ gene probe. The order of the $260 \mathrm{~kb}$ and the $124 \mathrm{~kb}$ fragments, representing Ap5 and Ap7, was determined by partial digestion of the DNA with ApaI in combination with hybridization experiments. The $l s p$ gene hybridized to the Ap3 fragment $(445 \mathrm{~kb}$ ) obtained by complete digestion with ApaI. With DNA partially digested with Apal the $l s p$ gene hybridized to a $570 \mathrm{~kb}$ fragment (data not shown), a finding which showed that the Ap7 fragment $(124 \mathrm{~kb})$ is positioned next to Ap3 and Ap5 next to Ap7 on the chromosome. 


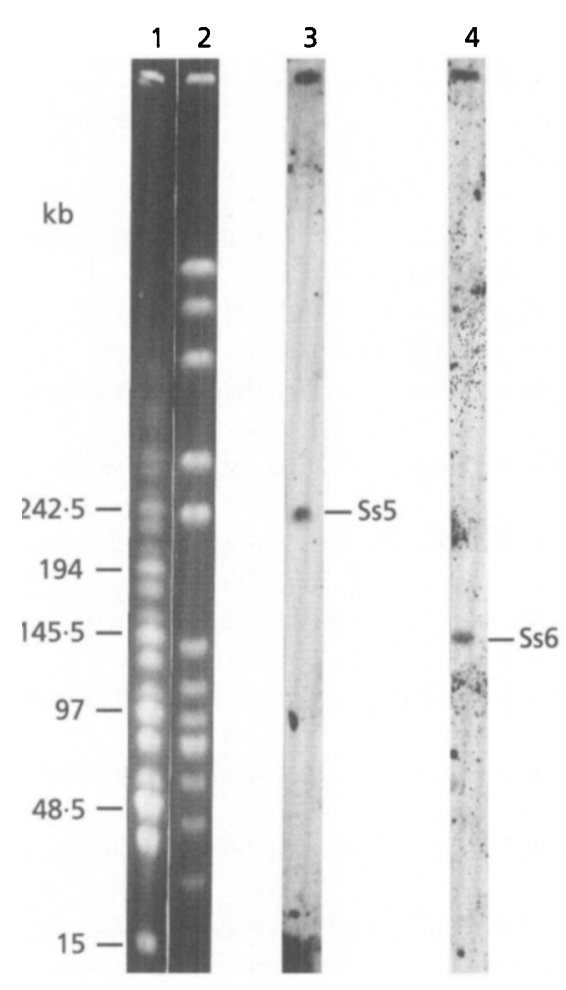

Fig. 2. DNA from S. carnosus digested with Sse8387I, separated by PFGE, blotted onto nylon membranes, and hybridized with different probes. Migration paramerters: $1 \%$ agarose, pulse times from 5 to $65 \mathrm{~s}$ at $170 \mathrm{~V}$ for $38 \mathrm{~h}$. Lanes: 1, MidRange PFG Marker 1; 2, Sse8387I-digested DNA; 3, hybridization of lane 2 with the $5.2 \mathrm{~kb}$ Ap12 fragment used as a probe; 4, hybridization of lane 2 with the $7.8 \mathrm{~kb}$ Ap11 fragment used as a probe.

The location of Ap6 (132 kb) and Ap10 (43 kb) in the gap between Ap5 $(260 \mathrm{~kb})$ and Ap4 $(415 \mathrm{~kb})$ was also determined by $A p a \mathrm{I}$ partial digestion and hybridization with the sceA gene probe. The sceA gene is localized on the Ap9 fragment $(52 \mathrm{~kb})$ obtained by complete digestion with Apal. After partial digestion, the sceA probe hybridized to $185 \mathrm{~kb}$ and $450 \mathrm{~kb}$ fragments (Fig. 3a), representing the Ap9-Ap6 and Ap9-Ap6-Ap5 partial digestion products, respectively. This showed the neighbouring position of the Ap9 and Ap6 fragment and confirmed the order of Ap5 (260 kb) and Ap7 (124 kb) also determined by partial digestion with $A p a \mathrm{I}$. The $m t l D-m t l F-m t l A$ genes hybridized to the $43 \mathrm{~kb}$ Ap10 fragment obtained after complete digestion with ApaI. After partial digestion with ApaI, these probes hybridized to a $460 \mathrm{~kb}$ fragment (data not shown). We also obtained a hybridization signal at $460 \mathrm{~kb}$ with the $s c e B$ probe (Fig. 3a), which is localized on the Ap4 fragment $(415 \mathrm{~kb})$. The $460 \mathrm{~kb}$ partial digestion product contained the Ap4 and Ap10 fragments. These results demonstrated that the $43 \mathrm{~kb}$ Ap10 fragment and the Ap4 fragment are positioned next to each other on the chromosome. The hybridization signal at $>800 \mathrm{~kb}$ (Fig. $3 a)$ represented the partial digestion product Ap10-Ap4Ap1.
The alignment of the remaining Ap11 fragment was performed by cross-Southern hybridization. A hybridization signal appeared only with Sse8387I-digested DNA, at about $142 \mathrm{~kb}$ (Fig. 2). This fragment (Ss6) was also mapped by partial digestion and hybridization with various gene probes. The sceA probe hybridized to the $142 \mathrm{~kb}$ Ss 6 fragment generated by complete digestion with Sse8387I, and to $240 \mathrm{~kb}$ and $360 \mathrm{~kb}$ fragments from partial digestions with Sse8387I (Fig. 3b). This indicated that Ss6 is positioned next to Ss8 $(97 \mathrm{~kb})$ and Ss7 $(115 \mathrm{~kb})$. The identical arrangement of these fragments was obtained in hybridization experiments with other gene probes. The alignment of these fragments and the cross-hybridization of the $7.8 \mathrm{~kb}$ Ap11 fragment to Ss6 revealed the localization of Ap11 in the remaining small gap between Ap10 (43 kb) and Ap9 $(52 \mathrm{~kb})$. The resulting physical map with NotI, SfiI, and ApaI sites is presented in Fig. 4. The Sse8387I fragments Ss1, Ss2, Ss3, Ss5, Ss6, Ss7 and Ss8 are also shown.

\section{Location of genetic markers on the chromosome}

Fifteen previously identified genes and gene clusters from $S$. carnosus were localized by Southern hybridization on the physical map (Fig. 4). The markers used for genetic mapping are described in Table 3. Fragments of the encoding regions of each of these genes or gene clusters were hybridized to digests of $S$. carnosus DNA, thereby defining the loci on the chromosome. All genetic markers were associated with specific restriction fragments. Hybridizing fragments are summarized in Table 3. The hybridization with some of the gene probes was also indispensable for the alignment of the NotI, SfiI and Apal fragments. Southern hybridization with probes corresponding to the $16 \mathrm{SrRNA}$ gene and to the $5^{\prime}$ end of the 23S rRNA gene were used to map the restriction fragments that contain the rRNA genes. With these probes we could identify four $r r n$ loci clustered in two different regions of the chromosome. They were positioned on the Ap4, No3, Ap8 and Ap6 fragments. The $23 \mathrm{~S}$ rRNA gene of $S$. carnosus contained an ApaI site (Ludwig et al., 1992). Therefore the $r r n$ genes could be localized at the junctions of Ap4-Ap10, Ap6-Ap5, Ap1-Ap8 and Ap8-Ap12.

\section{DISCUSSION}

By PFGE analysis, the chromosome size of $S$. carnosus was estimated to be $2590 \mathrm{~kb}$. This value is in the same order of magnitude as the size of $2750 \mathrm{~kb}$ determined for S. aureus (Pattee et al., 1990). The genomes of bacteria vary in size, from $600 \mathrm{~kb}$ for Mycoplasma genitalium to $9450 \mathrm{~kb}$ for Myxococcus xanthus (Cole \& Saint Girons, 1994). The S. carnosus chromosome could be placed among the larger genomes in group 2 with a size of $1500-3000 \mathrm{~kb}$. Micro-organisms with this genome size exist in the Archaeobacteria and in various Eubacteria such as Campylobacter, Enterobacter, Haemophilus, Helicobacter, Lactococcus, Neisseria and Streptococcus (Cole \& Saint Girons, 1994; Fonstein \& Haselkorn, 1995). 
(a)

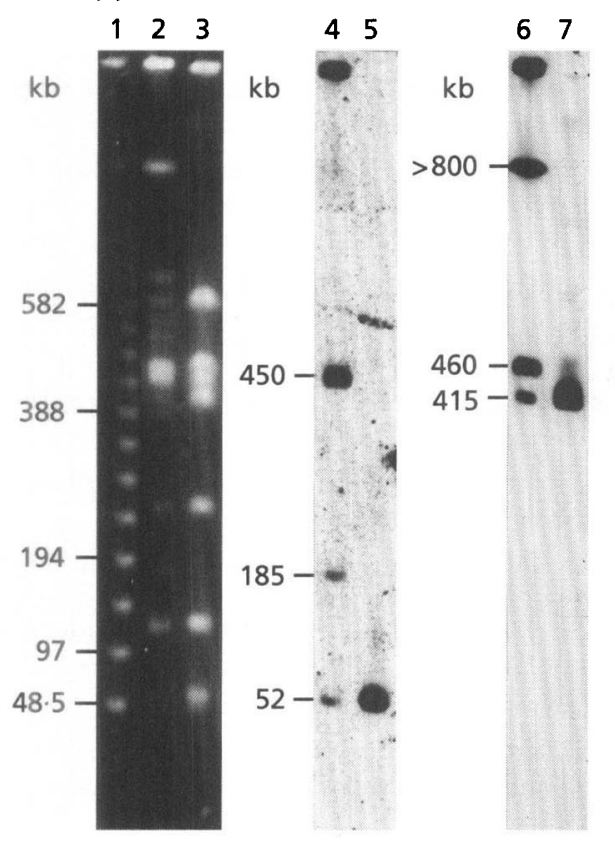

(b)

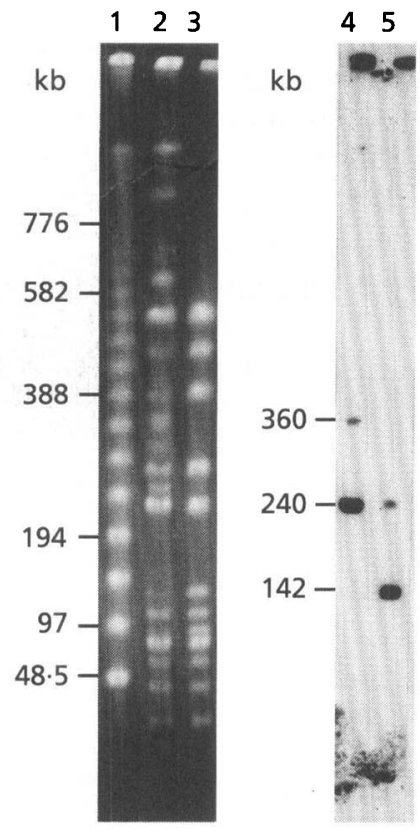

Fig. 3. DNA from $S$. carnosus digested with Apal or Sse8387I, separated by PFGE, blotted onto nylon membranes, and hybridized with various gene probes. (a) Migration parameters: $1 \%$ agarose, pulse times from 10 to $100 \mathrm{~s}$ at $170 \mathrm{~V}$ for $38 \mathrm{~h}$. Lanes: 1 , lambda DNA concatemers; 2, partial Apal digestion; 3, complete Apal digestion; 4, hybridization of DNA fragments in lane 2 with the sceA probe; 5 , hybridization of DNA fragments in lane 3 with the sce $A$ probe; 6 , hybridization of DNA fragments in lane 2 with the $s c e B$ probe; 7 , hybridization of DNA fragments in lane 3 with the sceB gene probe. (b) Migration parameters: $1 \%$ agarose, pulse times from 10 to $100 \mathrm{~s}$ at $170 \mathrm{~V}$ for $36 \mathrm{~h}$. Lanes: 1, lambda DNA concatemers; 2, partial Sse8387I digestion; 3, complete Sse8387I digestion; 4, hybridization of DNA fragments in lane 2 with the sceA gene probe; 5 , hybridization of DNA fragments in lane 3 with the sceA probe.

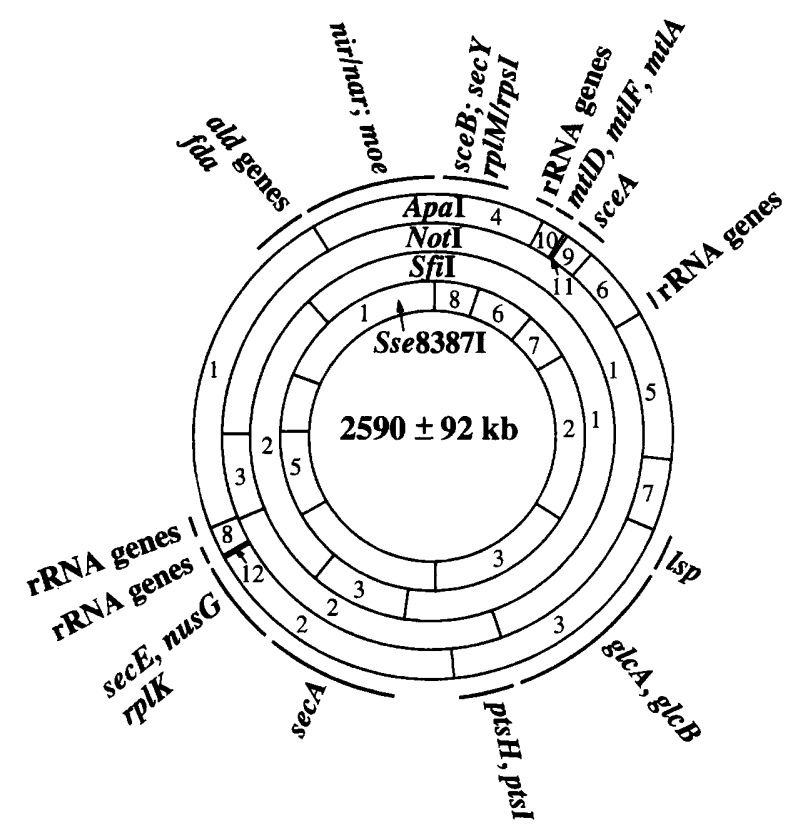

Fig. 4. Physical and genetic map of S. carnosus TM300 generated with Apal, Notl, Sfil and Sse8387I. The outer circle represents Apal fragments, the second circle Notl fragments, and the third circle Sfil fragments. The Sse8387I fragments Ss1, Ss2, Ss3, Ss5, Ss6, Ss7 and Ss8 represent part of the inner circle. Restriction fragments are numbered in order of their sizes (Table 1). Segments of the inner circle which are not numbered are not yet mapped. The locations of the genes are indicated by the arc lines outside the circle. For gene designations, see Table 3.

The physical map of $S$. carnosus was established by a combination of complementary techniques. The analyses of single, multiple and partial digests in combination with hybridization experiments with genetic markers and cross-Southern hybridization allowed the alignment of the NotI, SfII and ApaI fragments. Consecutive double digestions were used to confirm the localization of the fragments. This technique was also necessary for the unequivocal mapping of the ApaI fragments to locate some of the Sse8387I restriction sites. The data obtained were consistent with the concept of a single and circular chromosome in S. carnosus.

Both cross-Southern hybridization and consecutive double digestions analysed by two-dimensional electrophoretic separation of the fragments were affected by technical difficulties. Cross-Southern hybridization, in which labelled fragments produced by one enzyme are hybridized to fragments produced by another, often gave ambiguous results. The fragments to be labelled could not be obtained in sufficient purity because there was often a contaminating smear of degraded DNA in gel electrophoretograms. We therefore had to repeat these experiments several times with different DNA preparations to obtain unequivocal results. No1, Sf1 and NoSf1 were underrepresented in electrophoretograms because some slight non-specific DNA degradation probably occurred during extraction and incubation with the restriction enzyme. Another explanation may be that the DNA was isolated from exponentially growing bacteria containing replication forks. The relative amounts of the smaller fragments should be less susceptible to these interfering factors than those of the larger DNA fragments, since they offer a smaller target. The underrepresentation of the larger fragments may also be a reason for the failure to localize the Ap11 fragment on No1, Sf1 and NoSf1, and Ap12 on No2 and Sf 2 by cross-Southern hybridization.

Eighteen genetic loci were placed on the $S$. carnosus 
genome map. Four $r r n$ loci were found to be clustered in two regions separated by approximately $800 \mathrm{~kb}$. rrn locus grouping has been observed in many bacteria, such as Escherichia coli (Bachmann, 1990), Bacillus subtilis (Piggot, 1990), Lactococcus lactis subsp. lactis (Tulloch et al., 1991), Clostridium perfringens (Canard \& Cole, 1989), Haemophilus influenzae (Lee et al., 1989) and Streptococcus thermophilus A054 (Roussel et al., 1994). The rrn loci of $S$. carnosus were located in a region representing about half of the chromosome.

Many genes were found on the $415 \mathrm{~kb} \mathrm{Ap} 4$ fragment. In a first approach to map this region in greater detail, we determined the location of the Sse8387I sites. The nir/nar genes, involved in nitrite and nitrate reduction, and the moe genes, involved in the biosynthesis of the molybdenum cofactor, were located on a $290 \mathrm{~kb}$ ApaI-Sse8387I fragment. The sceB and secY genes were situated on the $97 \mathrm{~kb}$ Ss8 fragment. The genes $r p l M-r p s l$, encoding ribosomal proteins, are organized in an operon, which was also mapped on Ss8. The $r p l K$ gene, encoding the ribosomal protein L11, was positioned together with $\sec E$ and $n u s G$ on a $150 \mathrm{~kb}$ Sfil-Apal fragment. The secA gene was found on the neighbouring $220 \mathrm{~kb}$ Sfil fragment (Sf3).

The construction of a genomic map of the S. carnosus chromosome is a significant advance in the genetic analysis of this industrially important organism. Newly identified genes can now be easily mapped on the chromosome. By the use of additional restriction endonucleases and subcloning, regions of particular interest could be mapped in greater detail.

\section{ACKNOWLEDGEMENTS}

We are grateful to R. Freudel for providing plasmids pTY1, pUSE1, pMA16 and pBO23. We would like to thank E. Knorpp for excellent technical assistance, and K. A. Brune for critically reading the manuscript. This work was supported by the European Community (contract no. CIPACT9300145).

\section{REFERENCES}

Augustin, J. \& Götz, F. (1990). Transformation of Staphylococcus epidermidis and other staphylococcal species with DNA by electroporation. FEMS Microbiol Lett 66, 203-208.

Augustin, J., Rosenstein, R., Wieland, B., Schneider, U., Schnell, N., Engelke, G., Entian, K.-D. \& Götz, F. (1992). Genetic analysis of epidermin biosynthetic genes and epidermin-negative mutants of Staphylococcus epidermidis. Eur J Biochem 204, 1149-1154.

Ayora, S. \& Götz, F. (1994). Genetic and biochemical properties of an extracellular neutral metalloprotease from Staphylococcus byicus subsp. byicus. Mol Gen Genet 242, 421-430.

Bachmann, B. J. (1990). Linkage map of Escherichia coli K12, edition 8. Microbiol Rev 54, 130-197.

Canard, B. \& Cole, S. T. (1989). Genome organization of the anaerobic pathogen Clostridium perfringens. Proc Natl Acad Sci USA 86, 6676-6680.

Christiansen, I. \& Hengstenberg, W. (1996). Cloning and sequencing of two genes from Staphylococcus carnosus coding for glucose specific PTS and their expression in Escherichia coli K12. Mol Gen Genet 250, 375-379.
Cole, S. T. \& Saint Girons, I. (1994). Bacterial genomics. FEMS Microbiol Rev 14, 139-160.

Demleitner, G. \& Gotz, F. (1994). Evidence for importance of the Staphylococcus byicus lipase pro-peptide in lipase secretion, stability, and activity. FEMS Microbiol Lett 121, 189-198.

Dubitsky, A., Brown, J. \& Brandwein, H. (1992). Chemiluminescent detection of DNA on nylon membranes. BioTechniques 13, 392-399.

Fischer, R. \& Hengstenberg, W. (1992). Mannitol-specific enzyme II of the phosphenolpyruvate-dependent phosphotransferase system of Staphylococcus carnosus. Eur J Biochem 204, 963-969.

Fonstein, M. \& Haselkorn, R. (1995). Physical mapping of bacterial genomes. J Bacteriol 177, 3361-3369.

Gotz, F. (1986). Ein neues Wirt-Vektor-System bei Staphylococcus carnosus. Umschau 10, 530-537.

Götz, F. (1990a). Development of a cloning system in Staphylococcus carnosus: different processing of the Staphylococcus byicus lipase in Staphylococcus carnosus and Staphylococcus byicus. In Molecular Biology of the Staphylococci, pp. 273-281. Edited by R. P. Novick. New York: VCH.

Götz, F. (1990b). Staphylococcus carnosus: a new host organism for gene cloning and protein production. J Appl Bacteriol Symp Suppl 69, 49-53.

Gobtz, F. \& Schleifer, K. H. (1983). Staphylococcus carnosus und seine Verwendung in der Gentechnologie. Fleischwirtschaft 63, 1758-1760.

Götz, F. \& Schumacher, B. (1987). Improvements of protoplast transformation in Staphylococcus carnosus. FEMS Microbiol Lett 40, 285-288.

Götz, F., Kreutz, B. \& Schleifer, K. H. (1983). Protoplast transformation of Stapbylococcus carnosus by plasmid DNA. Mol Gen Genet 189, 340-342.

Heilmann, C., Schweitzer, O., Gerke, C., Vanittanakom, N., Mack, D. \& Götz, F. (1996). Molecular basis of intercellular adhesion in the biofilm-forming Staphylococcus epidermidis. Mol Microbiol 20, 1083-1091.

Klein, M., Meens, J. \& Freudel, R. (1995). Functional characterization of the Staphylococcus carnosus SecA protein in Escherichia coli and Bacillus subtilis secA mutant strains. FEMS Microbiol Lett 131, 271-277.

Kohlbrecher, D., Eisermann, R. \& Hengstenberg, W. (1992). Staphyloccocal phosphoenolpyruvate-dependent phosphotransferase system: molecular cloning and nucleotide sequence of the Staphylococcus carnosus ptsI gene and expression and complementation studies of the gene product. J Bacteriol 171, 3016-3024.

Kreutz, B. \& Götz, F. (1984). Construction of Staphylococcus plasmid vector pCA43 conferring resistance to chloramphenicol, arsenate, arsenite and antimony. Gene 32, 301-304.

Lee, J. J., Smith, H. O. \& Redfield, R. J. (1989). Organization of the Haemophilus influenzae Rd genome. J Bacteriol 171, 3016-3024.

Lerche, M. \& Sinell, H. J. (1955). Zum Vorkommen von Kokken in Rohwürsten. Arch Lebensmittelhyg 6, 194-198.

Liebl, W. \& Gotz, F. (1986). Lipase directed export of Escherichia coli $\beta$-lactamase in Staphylococcus carnosus. Mol Gen Genet 204, 166-173.

Liepe, H.-U. (1982). Bakterienkulturen und Rohwurst. Forum Mikrobiol 5, 10-15.

Linhardt, F., Ziebuhr, W., Meyer, P., Witte, W. \& Hacker, J. (1992). Pulsed-field gel electrophoresis of genomic restriction fragments as a tool for the epidemiological analysis of Staphylococcus 
aureus and coagulase-negative staphylococci. FEMS Microbiol Lett 95, 181-186.

Meens, J., Klose, R. \& Freudel, R. (1994). The Staphylococcus carnosus secE gene: cloning, nucleotide sequence and functional characterization in Escherichia coli secE mutant strains. FEMS Microbiol Lett 117, 113-120.

Neubauer, H. \& Götz, F. (1996). Physiology and interaction of nitrate and nitrite reduction in Staphylococcus carnosus. J Bacteriol 178, 2005-2009.

Niinivaara, F. P. \& Pohja, M. S. (1956). Über die Reifung der Rohwurst. I. Mitt: Die Veränderung der Bakterienflora während der Reifung. Z Lebensm-Unters-Forsch 104, 413-422.

Overhoff-Freundlieb, B. \& Freudel, R. (1991). Suppression of an Escherichia coli $\sec A^{\text {ts }}$ mutant by a gene cloned from Staphylococcus carnosus. FEMS Microbiol Lett 84, 143-150.

Pattee, P. A., Lee, H.-C. \& Bannantine, J. P. (1990). Genetic and physical mapping of the chromosome of Staphylococcus aureus. In Molecular Biology of the Staphylococci, pp. 41-58. Edited by R. P. Novick. New York: VCH.

Piggot, P. J. (1990). Genetic map of Bacillus subtilis 168. In The Bacterial Chromosome, pp. 107-145. Edited by K. Drlica \& M. Rily. Washington, DC: American Society for Microbiology.

Prévost, G., Jaulhac, B. \& Piemont, Y. (1992). DNA fingerprinting by pulsed-field gel electrophoresis is more effective than ribotyping in distinguishing among methicillin-resistant Staphylococcus aureus isolates. J Clin Microbiol 30, 967-973.

Rosenstein, R., Peschel, A., Wieland, B. \& Götz, F. (1992). Regulation and expression of the Stapbylococcus xylosus antimonite, arsenate and arsenite resistance operon. J Bacteriol 174, 3676-3683.

Roussel, Y., Pebay, M., Guedon, G., Simonet, J. M. \& Decaris, B. (1994). Physical and genetic map of Streptococcus thermophilus A054. J Bacteriol 176, 7413-7422.

Samuelson, P., Hansson, M., Ahlborg, N., Andréoni, C., Götz, F., Bächi, T., Nguyen, T. N., Binz, H., Uhlén, M. \& Ståhl, S. (1995). Cell surface display of recombinant proteins on Staphylococcus carnosus. J Bacteriol 177, 1470-1476.

Schleifer, K.-H. \& Fischer, U. (1982). Description of a new species of the genus Staphylococcus: Staphylococcus carnosus. Int J Syst Bacteriol 32, 153-156.
Schwartz, D. C. \& Cantor, C. R. (1984). Separation of yeast chromosome-sized DNAs by pulsed field gel electrophoresis. Cell 37, 67-75.

Snopková, S., Götz, F., Doskar, J. \& Rosypal, S. (1994). Pulsed field gel electrophoresis of the genomic restriction fragments of coagulase-negative staphylococci. FEMS Microbiol Lett 124, 131-140.

Strauss, A. \& Götz, F. (1996). In vivo immobilization of enzymatically active polypeptides on the cell surface of Staphylococcus carnosus. Mol Microbiol 21, 491-500.

Thumm, G. \& Götz, F. (1997). Studies on prolysostaphin processing and characterization of the lysostaphin immunity (Lif) of Staphylococcus simulans biovar staphylolyticus. Mol Microbiol 23, 1251-1265.

Tschauder, S., Driessen, A. J. M. \& Freudel, R. (1992). Cloning and molecular characterization of the secY genes from Bacillus licheniformis and Staphylococcus carnosus: comparative analysis of nine members of the SecY family. Mol Gen Genet 235, 147-152.

Tulloch, D. L., Finch, L. R., Hillier, A. J. \& Davidson, B. E. (1991), Physical map of the chromosome of Lacotococcus lactis subsp. lactis DL11 and localization of six putative rRNA operons. $J$ Bacteriol 173, 2768-2775.

Wieland, B., Feil, C., Gloria-Maercker, E., Thumm, G., Lechner, M., Bravo, J.-M., Poralla, K. \& Götz, F. (1994). Genetic and biochemical analysis of the biosynthesis of the yellow carotenoid 4,4'diaponeurosporene of Staphylococcus aureus. J Bacteriol 176, $7719-7726$.

Wieland, K.-P., Wieland, B. \& Götz, F. (1995). A promoterscreening plasmid and xylose-inducible, glucose-repressible expression vectors for Staphylococcus carnosus. Gene 158, 91-96.

Witke, C. \& Götz, F. (1993). Cloning, sequencing and characterization of the gene encoding the class I fructose-1,6-bisphosphate aldolase of Staphylococcus carnosus. J Bacteriol 175, 7495-7499.

Witke, C. \& Götz, F. (1995). Cloning and nucleotide sequence of the signal peptidase II (lsp)-gene from Staphylococcus carnosus. FEMS Microbiol Lett 126, 233-240.

Received 2 July 1997; revised 6 October 1997; accepted 13 October 1997. 